\title{
War Crimes of Rape in the Croatian War of Independence (1991 - 1995)
}

Sanja Kopunović Legetin* s.kopunovic@gmail.com

Suzana Vuletićs* suzanavuletic007@gmail.com

Stanislav Šota**** stanislav.sota@os.t-com.hr https://doi.org/10.31192/np.17.2.1

UDK/UDC: 343.541:355.4(497.54)“1991/1995“

2-48-058.65(497.54)

Izvorni znanstveni rad / Original scientific paper Primljeno/Received: 31. siječnja 2019. / January 31, 2019 Prihvaćeno/Accepted: 9. ožujka 2019. / March 9, 2019

The Đakovo-Osijek church is one of the archdioceses in the Republic of Croatia that suffered the most during the Greater-Serbian aggression from 1991 to 1995. With the deaths that occurred during the aggression and occupation, a large part of the population, especially the Vukovar region, was exposed to physical, psychological and emotional abuse after capture. In addition to expulsion, capture, forced labour, starvation, alienation, and appropriation of property in the occupied part of the Archdiocese, torture has occurred, especially the numerous rapes by the Greater Serbian aggressor. First part of this work talks about the nature of war as the most tragic event of civilization. The paper points to the crimes that characterize the Croatian War of Independence as every other war, emphasizing especially rape as the most brutal form of crime and war strategy, with all the possible causes and consequences of rape on a person. In the second part of the paper, parts of the results of the research conducted by the Suncica Association have been presented. The aim of the aforementioned research was to find specific attitudes, judgments, conditions and feelings of rape victims on the traumatic experience themselves, then discover and evaluate the quality of life of victims after the traumatic experience and identify the difficulties experienced by victims of traumatic experience today. Based on the research, the

* Sanja Kopunović Legetin, mag. theol, univ. spec. theol, Primary School »Draž«; Address: Ive Lole Ribara 1, HR-31305 Draž, Croatia.

** Suzana Vuletić, PhD, Assoc. Prof., University of Osijek, Faculty of Catholic Theology Đakovo; Address: Petra Preradovića 17, HR-31400 Đakovo, Croatia.

***: Stanislav Šota, PhD, Assis. Prof., University of Osijek, Faculty of Catholic Theology Đakovo; Address: Petra Preradovića 17, HR-31400 Đakovo, Croatia. 
work in the third section presents ways of dealing with the fact of the traumatic rape experience, emphasizing the need to provide social and even more spiritual assistance, showing a wide range of pastoral opportunities for the Church's action with the victims of war crimes of rape, always bearing in mind the need for interdisciplinary approach to this complex issue.

Key words: the Croatian War of Independence, Đakovo-Osijek Archdiocese, Greater-Serbian aggression, psychological assistance, rape, spiritual assistance, the Sunčica Association.

\section{Introduction}

War, as the most drastic form of conflicts caused by interests in various areas, leaves man an indelible trace. Wars often respect no rules or laws. All human rights and freedoms are violated, even basic ones. Crimes such as genocide, capture, physical, psychological and emotional abuse, rape, forced pregnancy, emigration, forced labour, starvation, robbery, extortion and appropriation of someone else's property have occurred in our region. Croatian people were also the participant and witness of such a form of traumatic experience during the Greater Serbian aggression against the Republic of Croatia. But the most brutal form of abuse, which is almost unspoken of, and which has left great consequences on victims at all levels of human existence, is a war crime of rape.

During the Croatian War of Independence in the territory of the ĐakovoOsijek Archdiocese, especially in the town of Vukovar and its surroundings, as well as throughout the country, many mass, brutal and monstrous rapes were carried out by the enemy army. For victims of war crimes of rape there has been serious damage to physical, mental, psychological and spiritual health, consequences of which are visible today. Some victims have spoken about the crime itself and the consequences of the same, but for some even today there is a vow of silence. Those who spoke were mostly encouraged by members of associations fighting for the rights of victims of war rape. The women of Vukovar and its surroundings (Borovo, Lovas, Opatovac, Bapska, Šarengrad, Ilok and others) decided to fight for their own recovery but also the normal life of all victims, motivated by the efforts of Ms. Marija Slišković, Sunčica Association president and the courage of the victims themselves. The lives of the mentioned victims show that recovery is possible, but first it is necessary for the victim to speak out and to return her reputation and dignity, offering legal, psychological, medical, social and spiritual assistance.

The traumatic experiences carry the lasting and severe consequences that are visible in our daily life, so we have chosen this subject to help the truth come to light, to have a better insight into the issue ourselves, and to think 
even more about ways to help victims of war rape. The tragedy of war rape is a complex issue, so it was necessary to look at the situation from multiple angles and approach issues interdisciplinary. This work comprehensively approaches the subject from the sociological, statistical, psychological and pastoral-theological perspective of observation.

In the first part, the paper briefly describes the nature of war and war rape, especially its causes and consequences. The second part of the paper brings part of the results of research conducted among the victims of the Croatian War of Independence on the crimes of rape and the consequences of these crimes. The third part seeks to highlight the need for different models and approaches to working with persons who were victims of rape during the Croatian War of Independence. Pastoral guidelines for working with victims are offered and presented, bearing in mind the need for interdisciplinarity. ${ }^{1}$

\section{War and War Rape - Causes and Consequences}

There are various definitions of war. One of them describes the war as an ethnocidal, ecocidal, and culturicidal event, which is consequently manifested in the destruction of human lives, natural, material, cultural and religious goods, and all this in the name of unjustified high-state goals. As such, it is the most tragic form of anti-humanism, anti-personalism and anti-culturalism. ${ }^{2}$ The basic aim of war is to achieve one's goal by threatening or realizing damage to others. The winner is the one who, whether more effectively terrorizes than the opponent, or is able to inflict more damage than he or she will endure. War is the most drastic form of conflict between socio-political entities, caused by conflicts of interest: economic, political, religious and ideological, in which the use of force (weapon) intends to destroy the opposite side. ${ }^{3}$

In most of the wars no rules are respected, not even war rules, but they are overwhelmed by personal, blind and primitive passions, and fanatic hatred of bullies and attackers. All the hardness, cruelty and tragedy of the war were felt throughout the whole of the country, almost on all the battlefields: East Slavonia, West Slavonia, Kordun, Lika, North Dalmatia and South Dalmatia, and on some of them the cruellest atrocities and destruction took place. The

\footnotetext{
${ }^{1}$ The paper is a revised and partially reworked part of the Sanja Kopunović Legetin's specialist's thesis entitled War Crimes of Rape During the Croatian War of Independence in the Territory of the Đakovo-Osijek Archdiocese and Attempts to Provide Psychosocial and Spiritual Assistance to Victims, within the Postgraduate Specialist Study of Pastoral Theology, course: Pastoral Work in Crisis Situations, at the Faculty of Catholic Theology in Đakovo, defended on September 13, 2017, made under the direct guidance of Stanislav Šota, and her mentor Suzana Vuletić (https://zir. nsk.hr/islandora/object/djkbf:90/preview).

${ }^{2}$ Cf. N. SKLEDAR, Žena i rat, Zaprešićki godišnjak, 3 (1993) 85-89, 85.

${ }^{3}$ Cf. D. MARIJAN, Domovinski rat, Zagreb, Despot infinitus, Hrvatski institut za povijest, 2016, 391-392; Skledar, Žena i rat..., 85.
} 
Đakovo-Osijek Archdiocese, then the Đakovo and Srijem Diocese, was the most affected by the destructions of war of all dioceses in Croatia, with the largest number of people killed, wounded, deported and displaced from their homes. It is evident that the entire country felt the cruelty of war, but also various forms of war violence. War violence includes torture, genocide, rape, sexual slavery and forced pregnancy as a violation of international humanitarian law. ${ }^{4}$ War crimes against a civilian population constitute a special group, that is done by anyone who violates the rules of international law, during a war, armed conflict or occupation, by ordering an attack on a civilian population, a settlement, individual civilians or persons unable to fight resulting in death, severe bodily injury, severe health distress, a non-target attack on civilian populations, killing, torture and inhumane treatment, involving serious suffering or bodily harm or health damage to a civilian population, carrying out displacement or relocation, forcing rape and prostitution, implementing measures of intimidation and terror, hostage taking, collective punishment, detention in concentration camps and other unlawful detentions, such as forced labour, hunger, robbery, destruction and apprehension of other people's property. ${ }^{5}$ All of the aforementioned were used as a war strategy in the Croatian War of Independence by the enemy army, and war rape for its brutality and perversion goes beyond all the above-mentioned cruel acts. In the following, we will try to look at the causes and consequences of war rape.

When we talk about the causes of war rape, we must look at the facts from several aspects. Rape by itself is mostly not a result of sexual desire and lust, but the bond of sexuality and feelings of power and superiority of a man over a woman, and in the war, it emphasizes the superiority over the hostile nation and the punishment to all men of the opposed ethnic community. ${ }^{6}$

War rape is a means to confirm the diversity of power among the warring parties, the supremacy of men over women, ${ }^{7}$ and the desire for the genocide ${ }^{8}$ of

${ }^{4}$ M. MAMULA, Seksualno nasilje - teorija i praksa, Zagreb, Ženska soba, 2005, 52.

${ }^{5}$ Cf. Ž. HORVATIĆ (ed.), Rječnik kaznenog prava, Zagreb, Masmedia, 2002, 501-502.

${ }^{6}$ Cf. J. ČAČIĆ-KUMPES, Etničnost, rat i silovanje, Migracijske teme, 8 (1992) 2, 95-104, 98; S. MESZAROS, Ratno seksualno nasilje nad ženama i Međunarodni sud za ratne zločine počinjene na području bivše Jugoslavije. Prostori disjunkcije, Diskrepancija - studentski časopis za društveno-humanističke teme, 5 (2004) 9, 9-12.

7 Cf. S. BROWNMILLER, Protiv naše volje. Muškarci, žene i silovanje, prev. N. Hewitt (Against Our Will: Men, Women and Rape, 1975) Zagreb, Zagorka, 1995, 14; S. FABIJANIC GAGRO, Zločin silovanja u praksi Međunarodnog kaznenog tribunala za bivšu Jugoslaviju i Međunarodnog kaznenog tribunala za Ruandu, Zbornik Pravnog fakulteta u Zagrebu, 60 (2010) 6, 1309-1334.

${ }^{8}$ Cf. Horvatić (ed.), Rječnik kaznenog prava..., 94-95; According to the Criminal Law Dictionary, the word genocide comes from the Greek word genos (race, kind, tribe) and the Latin word occidere (kill), and the name itself comes from Polish lawyer Raphael Lemkin. The rape of hostile nation's women in a war takes on the form of genocide if it is done with the aim of destroying a national, ethnic, racial or religious group: the physical and mental health of victims is disturbed and the children of the warring parties are born. 
the hostile nation, where the destruction of the female body represents the destruction of the other nation and country. ${ }^{9}$ Women are seen as the bearers of biological reproduction that multiply the nation, but also the bearers of ideological reproduction because they play the role of educator and transmitter of national identity.$^{10}$ Those who have become pregnant during rape have lasting consequences, regardless of whether a child has been born or aborted. If a child is born, the female body is again a carrier of the message of the hostile nation because the ethnic community was destroyed by mixing nations in which the father of the born child is a member of the opposing ethnic group and symbolizes the destruction of the hostile ethnic community. ${ }^{11}$ A woman in war is a means of securing genocide: apart from the fact that the bully destroys human lives, material and cultural goods, by carrying out a rape, the rapist tells the defeated to disappear from a certain territory. Rape as part of a war strategy aims to expel the population and as such has become a method of warfare and ethnic cleansing. The raped women left the areas where the crime of rape occurred so that they would not be stigmatized, and those who were not raped emigrated preventively for fear that the terrible crime could happen to them at the same place.

Women who were raped during the war had no choice: they were raped only because they were women of other nationality and faith. After many years the victims are still being interrogated and further humiliated in court with numerous questions, and it is logical that many do not want to go to court. For this reason, they carry the trauma and the inability to fairly punish the perpetrator of the criminal offense whole their life. Although war crimes of rape are a serious offense that leaves the victims great and lasting consequences, the truth about rape in general, and especially in the war, is difficult to prove: most victims are silent and carry their burden alone, the data is not verifiable, victims and witnesses are often reluctant to talk about the rape and torture at all, but all sources agree on the following: war rapes were massive, girls between seven and fourteen were raped, eighty-year-old women were raped, and most often girls and women between the ages of twelve and thirty-five; daughters were raped in the presence of parents, mothers in the presence of children and wives in the presence of their husbands. ${ }^{12}$ In the Croatian War of Independence, members of the hostile Serbian army often threatened their lives or lives of their loved ones if they disagree with the sexual act, and they often did not succeed in saving either themselves or their close ones from the cruel crime of

\footnotetext{
${ }^{9}$ Cf. Mamula, Seksualno nasilje - teorija i praksa..., 53.

${ }^{10} \mathrm{Cf}$. Čačić-Kumpes, Etničnost, rat i silovanje..., 101; Mamula, Seksualno nasilje - teorija i praksa..., 54; V. POZAIĆ, Odgovornost u vrtlogu rata. Primjer: Genocid - silovanje, Obnovljeni život - časopis za filozofiju i religijske znanosti, 48 (1993) 3-4, 287-307, 293-294.

${ }^{11}$ Cf. Mamula, Seksualno nasilje - teorija i praksa..., 56-57; Pozaić, Odgovornost u vrtlogu rata..., 300-302.

${ }^{12}$ Cf. Čačić-Kumpes, Etničnost, rat i silovanje..., 99.
} 
rape. The humiliation was so felt not only by a raped woman but by an entire community that was unable to help her. Women who became pregnant by rape were often detained in detention camps until the near end of their pregnancy, and were only then released or taken to be exchanged..$^{13}$ Thus we can talk about various forms of war-related abuse ${ }^{14}$ which are mutually intertwined: the act of rape was preceded by the act of abduction and forced deportation to unknown objects, and during and after rape victims were mentally and physically abused in different ways.

In addition to rape, the form of cruel war violence that women were exposed to, is war prostitution as a form of exploitation of a woman's body, whereby a woman voluntarily becomes an object of the sex act to an enemy ethnic group just to survive it alone and more often to protect her own children and closer family from physical, psychological and sexual abuse. The most common feeling that appeared in all raped women is fear: whether they will be raped again, possibly killed, whether they will get pregnant, what will happen with their lives, if they survive the rape and the war at all, ${ }^{15}$ how will they deal with the trauma of rape which itself is huge and tough, how will they continue to move alone because their husbands and family members were killed or were still on the battlefield etc. Burdened by a sense of shame, humiliation, and prejudice due to patriarchal upbringing, they also fought with a conviction of their environment. Frequently, there was fear of even thinking about a future contact with any man. The stigmatized identity reflected the woman, but also the children born of such circumstances. Surviving the rape was a reason for not going back to the ruined homes to suppress images of humiliation, destruction and killing, to oblivion. ${ }^{16}$

As rape leaves the victim a deep trace and indelible consequences, the victim's family also suffers for the same, as well as the whole community whose honour and sense of dignity are disrupted. ${ }^{17}$ Although it is a crime that affects the wider community, there are several reasons why victims decide on silence and non-reporting of the crimes and the criminals: there is fear of blame, disbelief and ridicule, of the reactions of family and close persons, as well as pressure and persuasion of close persons that the victim does not report the crime, the raped woman's own feeling of weakness to go through all the police and judicial procedures, and the fear that the rapist will avenge her or a close

\footnotetext{
${ }^{13}$ Cf. D. VEČERINA, Silovanje - ratni zločin, Odvjetnik - časopis Hrvatske odvjetničke komore, 68 (1995) 9-10, 95-99, 98-99.

${ }^{14}$ Cf. Mamula, Seksualno nasilje - teorija i praksa..., 57.

${ }^{15} \mathrm{Cf}$. Čačić-Kumpes, Etničnost, rat $i$ silovanje..., 101-102.

${ }^{16}$ Cf. J. LEWIS HERMAN, Trauma i oporavak, Zagreb, Druga, 1996, 139-142.

${ }^{17}$ Cf. B. BRKIĆ, Kaznena djela protiv spolne slobode i spolnog ćudoređa te poseban osvrt na silovanje i bludne radnje. Teorijski i praktički aspekt te problem međusobne distinkcije, Hrvatska pravna revija, 3 (2003) 2, 8-18, 99.
} 
relative if she reports the crime. Though widespread, sexual violence is poorly criminalized and punishments for rapists are low: from one to ten years. ${ }^{18}$

All the above shows that rape is a traumatic experience and every raped person deals with the consequences of the same in their own way. We can divide them into: physical, related to bodily injury, reproductive organs, the possibility of contagious sexually transmitted diseases and unwanted pregnancy; social, such as labelling, stigmatization and rejection of a person; and psychological consequences that imply disrupted mental and sexual health, self-confidence and self-esteem, traumatic reactions and disorders. ${ }^{19}$

The fact that marks every raped person is the hard truth that physical violence and psychological trauma have long-term consequences. The survived raped women describe a set of symptoms called Rape Traumatic Syndrome (RTS) involving physical and psychological reactions and behavioural changes. ${ }^{20}$ RTS can be described as a PTSD specifically characterized by traumatic rape experiences, in the context of the socio-cultural environment the traumatized person belongs to and the victim's family status. The rape traumatic syndrome is a wider term than PTSD because it involves physical and psychological changes, as well as changes in victim's behaviour that are the result of the experience of sexual violence. Some victims of sexual violence in the Croatian War of Independence have spoken out about the crime itself and its consequences, but some still do not want or are unable to do so because of the hurt.

If we try to summarize the basic subjective and behavioural problems of the victims of rape and sexual abuse, which the victims themselves testify, it could be said that the victims feel: ashamed, humiliated, depressed, broken, marked, dirty, worthless, they are constantly returning to traumatic events in dreams, thoughts and memories, reconsider the possibility of their own guilt for that incident, feel the anger and bitterness because it happened to them, do not trust people, some do not feel any satisfaction in life, nor have any interest in anything. ${ }^{21}$ The endured crime of war rape as a traumatic event leaves the victim with a long-lasting emotional, thought-related, bodily and behavioural reactions. Because of their suddenness and strength, people are brought into a state of helplessness and fear, but in the long run to insecurity in life and the meaning of the same. All the above refers to the wide range of consequences that victims of rape have to face, but the problem rarely mentioned, and which is very much present is talking of rape as a devastating act for family and friends of rape victims, who also pass certain stages of dealing with trauma: from disbelief and shock, blaming the abuser, but also themselves, rage and

\footnotetext{
${ }^{18}$ Cf. Mamula, Seksualno nasilje - teorija i praksa..., 30-35.

${ }^{19} \mathrm{Cf}$. Mamula (ed.), Seksualno nasilje u Hrvatskoj..., 8-16.

${ }^{20} \mathrm{Cf}$. L. KELLY, Preživjeti seksualno nasilje, Zagreb, Ženska soba - Centar za seksualna prava, 2008, 183-212.

${ }^{21}$ Cf. Arambašić, Psihološka prva pomoć..., 280-283.
} 
anger, anxiety and fear, silence about the crime, and general disorientation in new situation..$^{22}$

Summing from all the above, it is important when providing support and help to use a variety of methods and to continuously work on restoring the sense of security and confidence in the world and life, integrating trauma into one's own life experience. ${ }^{23}$

\section{Victims of Croatian War of Independence on the War Crimes of Rape}

The members of the Sunčica Foundation ${ }^{24}$ spoke to us both in individual and group interviews of violence in general, war rape with possible causes, the consequences visible on victims and their families, misunderstanding and living with tragedy of rape and struggling with the authorities and laws in general.

The survey entitled War Crimes of Rape During the Croatian War of Independence in the Territory of the Đakovo-Osijek Archdiocese and the Attempt to Provide Psychosocial and Spiritual Assistance to Victims aims to check the opinions, attitudes and feelings of victims of traumatic experience, detect and assess the quality of life after traumatic experience and identify difficulties which victims of traumatic experience encounter in life to improve and enhance the psychosocial and spiritual care they need.

The said study ${ }^{25}$ included 20 participants, of which 1 (5\%) man and 19 (95\%) women.

${ }^{22}$ Cf. Mamula, Seksualno nasilje - teorija i praksa..., 24.

${ }^{23}$ Cf. Arambašić (ed.), Psihološka prva pomoć..., 26-29.

${ }^{24}$ The Sunčica Foundation was established as the first institutional support for victims in seeking legal protection, at the proposal of the City of Zagreb and the Office for War Veterans. Encouraged by the Association of Women in Croatian War of Independence victims of war spoke out, and their testimonies were published in the book named Sunčica according to which the eponymous documentary film was also recorded. The foundation was named after the then eight-month-old girl Sunčica, who was detained with her mother in Vukovar. The mother was locked in the apartment and set for rapes. When Sunčica was crying and interrupting her mother being raped by Serb soldiers, they would throw military jackets on her to put her to silence. Although she was detained as a new-born and the victim of an occupation policy, Sunčica has survived all ill-treatments and the Foundation carries the name after that little hero.

${ }^{25}$ The survey, written by the author, is named War Crimes of Rape During the Croatian War of Independence in the Territory of the Đakovo-Osijek Archdiocese and the Attempt to Provide Psychosocial and Spiritual Assistance to Victims. The respondents were victims of rape during the Croatian War of Independence and live in the territory of the Đakovo-Osijek Archdiocese, more specifically in the area of Vukovar and its surroundings. 20 respondents participated anonymously in the survey and responded to a total of 64 different questions pertaining to the form of violence applied to them, the length of the period spent in captivity, the consequences of rape afterwards, the internal state after the painful act, the ways to overcome the difficulties and trauma caused by rape and many others. In this part of the paper, we will only look at 
GENDER

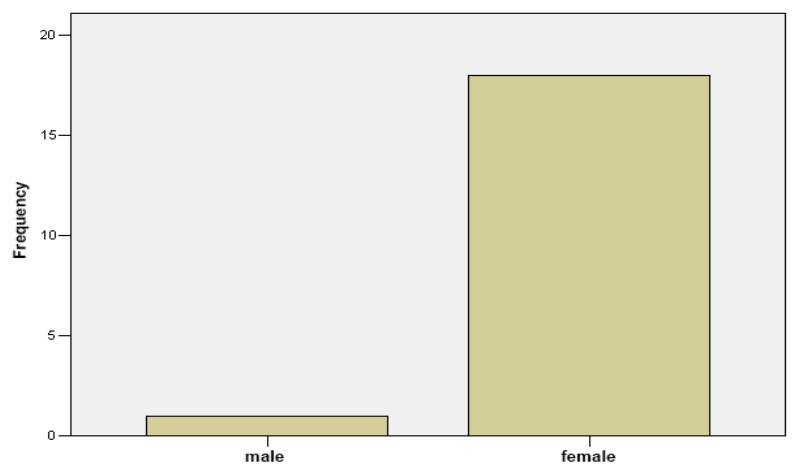

\begin{tabular}{|l|l|c|c|}
\hline \multicolumn{2}{|c|}{ Value } & Frequency & Percentage \\
\hline & Male & 1 & 5.0 \\
\hline & Female & 18 & 90.0 \\
\hline & Total & 19 & 95.0 \\
\hline Missing & & 1 & 5.0 \\
\hline Altogether & 20 & 100.0 \\
\hline
\end{tabular}

With respect to age, $40 \%$ of participants are in the range of 40 to 61 years, and $35 \%$ of participants are older than 61 years, meaning that 25 years ago, during the Croatian War of Independence, the victims were in average 30 years old.

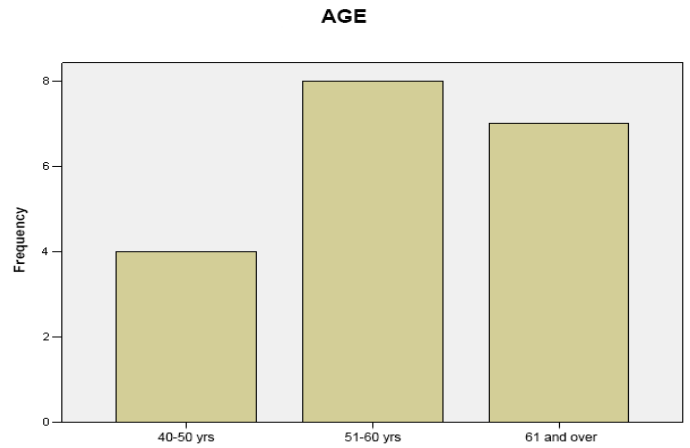

the answers to some of these questions that we consider to be an immediate indication of the torture the victims have experienced. The respondents in the survey answered to closed and open type questions and with Likert scale ranging from 1 to 5 (from I strongly disagree to I strongly agree). The time to answer the questions in the survey was unlimited, and the survey can be used individually or in a group. The survey was not reviewed or approved for use, and this is its first validation without a previously established procedure for determining the validity of the survey. The research was conducted in September and October 2016, and the data was processed by Monika Ećimović, MEdPsych. 


\begin{tabular}{|l|l|c|c|}
\hline \multicolumn{2}{|c|}{ Value } & Frequency & Percentage \\
\hline & $40-50$ & 4 & 20.0 \\
\hline & $51-60$ & 8 & 40.0 \\
\hline & 61 and more & 7 & 35.0 \\
\hline & Total & 19 & 95.0 \\
\hline Missing & & 1 & 5.0 \\
\hline Altogether & 20 & 100.0 \\
\hline
\end{tabular}

One of the important pieces of data we wanted to get through this research was whether the respondents were detained in the camp and how much their detention lasted. Responses to the survey showed that $80 \%$ of the participants were detained in the camp, $15 \%$ of the victims were not detained in the camp, but claimed to have remained in their town during the Croatian War of Independence, while only $5 \%$ did not answer the question.

\section{Confinement in detention camp}

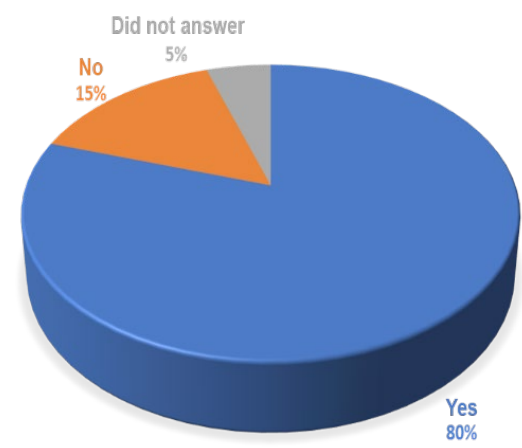

In the description of the rapist, the respondents stated in a large percentage of $75 \%$ that they did not know the rapists before rape, $15 \%$ of them knew, while $10 \%$ of respondents did not answer the question.

Knowing the rapist

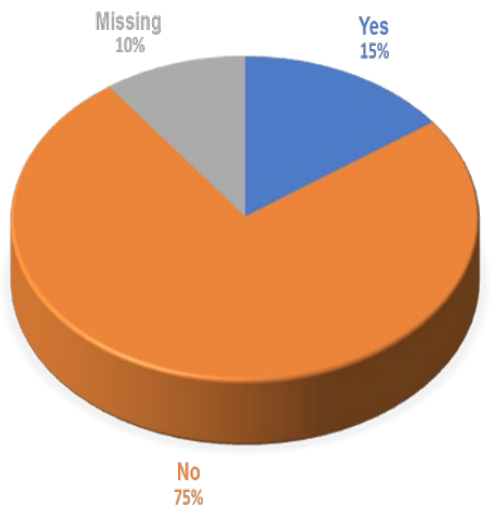


The next trauma of which the respondents spoke was the exposure to group rape to which $40 \%$ of the participants were exposed, $50 \%$ did not, while $5 \%$ of the participants spoke about the state of unconsciousness during the rape and did not know whether it was a group rape. $5 \%$ of participants did not answer this question.

\section{Exposure to group rape}

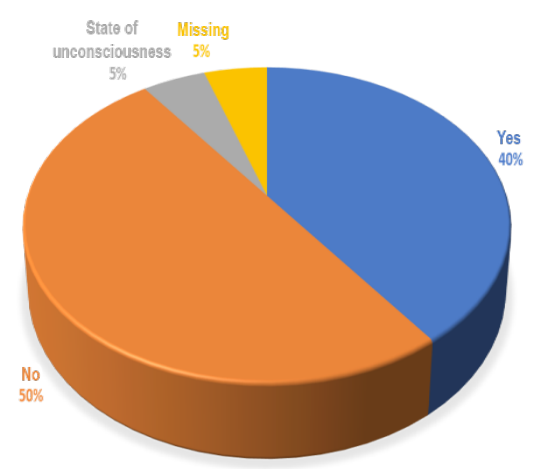

After the traumatic experience of a war crime, the large number of respondents asserted that the dominant feeling was shame, then depression, tension, sleep disturbance, anger, and to a lesser extent guilt and nutritional disorder. Some spoke of a strong sense of despair, horrific humiliation, sadness and emptiness, and some pointed out the desire for vengeance.

This type of traumatic event does not leave a trace only on the victim but also on marital-family relationship with a spouse. Some of the victims became widows in the war, marriages failed to some of them, and to those whose marriages survived marital relationships are mostly disrupted: rape is not being mentioned, the victims are locked in, they cannot stand being touched and they are very difficult to have sexual intercourse. The wider family mostly did not support them but were silent about the rape, covering up the truth with the aim of preventing the entire family from being disgraced and believing that the victim would be easier if the rape is not spoken about.

Due to the traumatic experience, poorly understood by the family and the wider community, the victims mostly had to find a strategy to face the truth themselves. To the great majority, there was work therapy and conversation with victims who experienced the same tragedy that helped, as well as prayer communities, pilgrimages, spiritual renewals and the sacrament of confession, and for a certain percentage the assistance of psychiatrists and pharmacology. 
Strategies for facing the truth

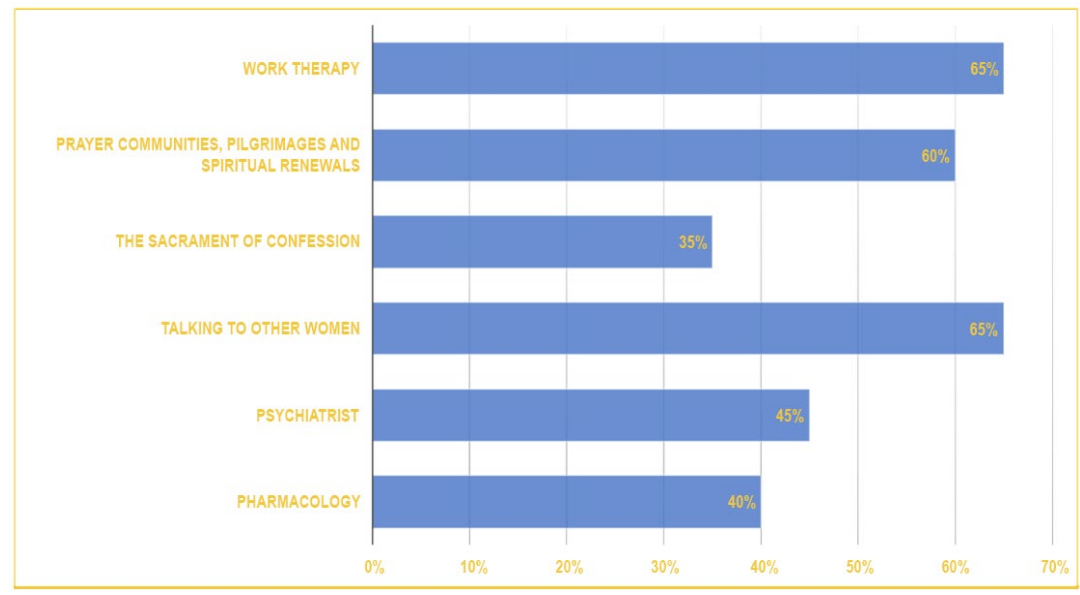

The last question addressed to the respondents is on their opinion and attitude to what they expect from the Church regarding the help to people who have experienced hell in the form of the war crime of rape, and the answers are different. In the survey, we left the vacant position for the respondents to reflect and express their own view of the Church as a religious institution whose mission is, among other things, based on the Word of God and the sacrament to provide nourishment to the tired and burdened ones.

Activities of the Church as an Institution working with People raped in Croatian war of independence

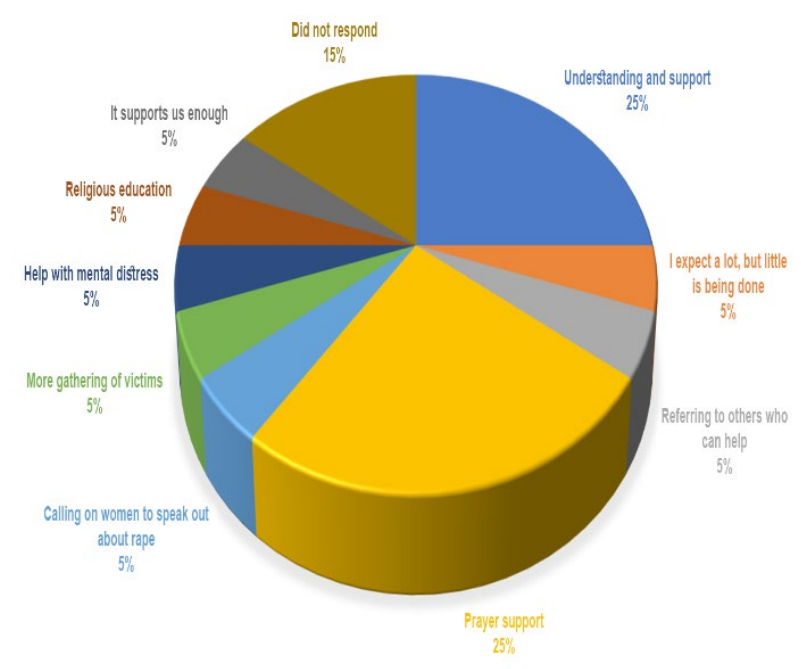


Expectations from the Church as a religious institution are different, and they come down to prayer support, understanding and support, encouragement, more gatherings and spiritual renewals.

Marked by the traumatic experience of war crimes of rape, facing the truth in various ways, the victims spoke of the difficulties they still live with today. Very important topics that were out of the scope of the survey have emerged. The members of the Sunčica Association, being at the same time the people living with the traumatic experience and consequences of the war crimes of rape during the Croatian War of Independence, spoke about the severity of their own trauma. Questions and answers, as well as ideas and constructive suggestions, came out spontaneously complementing one another. Speaking of the very act of rape, they think it is the worst crime against man and humanity. The majority of interviewees are concerned with abolition denouncing the war crime of rape as an act that leads to the need for criminal proceedings. They compare the situation in the Republic of Croatia and in Vukovar, where public service is carried out by those who have raped women and mothers of Vukovar until recently, to situation in other countries where this is inconceivable, also mentioning the legislation of the International Tribunal that speaks of rape as a way of warfare and is therefore calling rape criminal offense. Victims believe that because of bad politics there are no accurate data on the total casualties, the number of missing and killed. This has violated international law, and the victim is denied the crime and the right to satisfaction. After the brutal act of rape by the hostile army, another crime followed: ignoring the victims before the law, abolition, misunderstanding and condemnation by the community and close persons. Some of the victims found the strength and acknowledged the truth, and the shift to revealing the truth was initiated by the founding of the Sunčica Foundation and the actions of its administrator, who should be credited for gathering the victims of the Croatian War of Independence who, encouraged by the bravery of the members who shared the same fate, spoke out about the crime of rape during the war. The Foundation continuously collects testimonies and informs the public about the truth about rape and war crimes, presents documentary materials, arranges film and literary productions, organizes forums and round tables, and in various other ways fights for the truth. Encouraged by their testimony, members talk about their own traumatic experience, and most of them have been given satisfaction before the law. However, they emphasize that material indemnity is secondary because it is only a written acknowledgment of the recognition of the crime committed, which in fact creates a sense of reparation. They call on all men and women who were raped to speak out, to enter their community, to spread the truth to their people and to the world, and to seek reparation before the law. They point out that it is important to approach the victims because they will most likely remain silent and suffer if we do not find the right approach to them. The Law 
on the Rights of Victims of Sexual Violence during the Aggression against the Republic of Croatia in the Croatian War of Independence ${ }^{26}$ was passed thanks to the commitment of the aforementioned Foundation, which was perceived as a major breakthrough in the case of the reparation of victims of war rape.

\section{The Need to Provide Psychosocial and Spiritual Assistance to Victims}

The process of recovery in all types of crimes, especially when it comes to rape, is a very long and troublesome process, and it is more successful if the victim has the support and understanding of the community. When providing support and assistance to victims, various methods and continuous work need to be used to restore the sense of security and confidence in the world and life, enabling victims and their family members to integrate trauma into their own life experience. ${ }^{27}$ In order for the victim to succeed, it needs psychosocial assistance from experts, but also the entire community. Psychosocial assistance is key to the process of psychological and social empowerment of an individual, his family, and the entire environment to find ways and means to successfully face stress and overcome the crisis and traumatic experience, and gradually build a healthy lifestyle. Since this is a demanding process involving the victim and facilitator, it must be well planned, programmed, and thoughtfully lead to provide assistance. ${ }^{28}$

It is therefore important in all ways through all the media, modern technology, professional lectures and in particular the testimonies of those who have spoken out, to motivate and encourage the victims to speak about the crime experienced; Only then will they help primarily themselves, but also others, and bring out the truth. Only after acknowledging the truth, which is the first step, the victim can be provided with legal, psychological, social and spiritual assistance. The victims testify that suppression of feelings and memories over a number of years resulted in destruction of personality and severe mental suffering. In order to mitigate the consequences of war crimes of rape and to prevent even more destructive episodes for spiritual, mental, psychological and physical health, it should be openly talked about the crime itself and its consequences first and foremost with professionals, representatives and members of the associations dealing with victims of war abuse. Victims of war crimes of

\footnotetext{
${ }^{26}$ Cf. https://www.zakon.hr/z/794/Zakon-o-pravima-\%C5\%BErtava-seksualnog-nasilja-za-vrijeme-oru\%C5\%BEane-agresije-na-Republiku-Hrvatsku-u-Domovinskom-ratu (17.10.2016).

${ }^{27}$ Cf. L. ARAMBAŠIĆ (ed.), Psihološke krizne intervencije. Psihološka prva pomoć nakon kriznih događaja, Zagreb, Društvo za psihološku pomoć, 2000, 26-29; M. SZENTMARTONY, Osjetljivost za čovjeka. Pastoralna psihologija, Zagreb, Glas Koncila, 2009, 206-208.

${ }^{28}$ Cf. D. AJDUKOVIĆ, Planiranje, programiranje $i$ vođenje psihosocijalne pomoći, in: J. PREGRAD (ed.), Stres, trauma, oporavak, Zagreb, Društvo za psihološku pomoć, 1996, 247-255.
} 
rape are still having difficulties in handling the mentioned issue of social note. It is evident that in various ways they are facing their tragedy, but many have confirmed that their greatest difficulty is facing and bearing with the trauma of their closest ones..$^{29}$ Many victims have never talked to members of the family about the war crime of rape, although both family members and victims know that the truth is only suppressed in this way. Some of the victims were even silenced by members of the family and encouraged not to talk about rape, being told that it happened to others and that they survived, and not to bring shame on their husbands and families by seeking legal rights and punishment for the rapists. The spouses of some of the members of the Association, who have even been given reparation before the law, still think that their wives should have been silent about the rape. Victims are having difficulties with their household members, and are often being condemned, misunderstood and labelled by the society: some people speak of rape as something the victims deserved, caused themselves or at least could have prevented, and similar. ${ }^{30}$

Victims of war rape during the Croatian War of Independence need the help of society to restore self-esteem, self-confidence, restore the meaning of life, ${ }^{31}$ and dignity to themselves, although their dignity, according to Pope John Paul II, was not taken away because it is in the essence of human beings and therefore inalienable. From all of this, a great need is evident for psychosocial and spiritual assistance to victims and their family members who have hard time dealing with the various consequences of traumatic experiences of war crimes of rape, primarily their mothers, wives and children, but also men who are in the opinion of many more difficult to deal with reality. A great role in restoring basic human values has the Church, providing spiritual help to the victims.

The Church, as a religious institution, is called upon to every man, especially the one in need and distress and existential problems, to provide a helping hand and in the light of faith help to rise from the mud of evil. In this regard, it is very important to point out the positive influence of religiosity and religious practice in the form of sacraments, primarily the sacrament of reconciliation and the Eucharist, spiritual renewal and exercise, personal and community prayer, meditation and the like, on the mental health of man. The role of religion in general, especially Christianity and the mission of the Church, is manifested in the expressed concern for the person in distress: it is necessary to be with these persons, to counsel them, to instruct, to support, and sometimes just to be close, to actively listen to the victims and to pray for them and with them. In addition to practical help, a believer is called upon in God's Word to focus

\footnotetext{
${ }^{29}$ Cf. M. MITROVIĆ, M. ŠIMEK, Trauma i samopomoć. Priručnik za rad s razvojačenim braniteljima, Osijek, Edukacijska kuća Centra za mir, nenasilje i ljudska prava [Educational House of the Center for Peace, Nonviolence and Human Rights in Osijek], 2004, 16.

${ }^{30} \mathrm{Cf}$. J. Čačić-Kumpes, Etničnost, rat i silovanje..., 101.

${ }^{31}$ Cf. P. M. ZULEHNER, Pomozite ljudima živjeti. Za novu klimu u pastoralu, Đakovo, Biskupijski ordinarijat, 1986, 41.
} 
on a person and their specific problem and in the light of faith to help to stand up. The foundation of the Church's mission lies in Jesus' order to the disciples to go throughout the world and proclaim the gospel to every creature (Cf. Mk 16, 15). Pastoral care consists of caring for one another (Cf. 1 Cor 12:25), as well as for all people (Cf. 2 Cor 11:28). It is motivated by human concern and uses the gospel and the evangelical means to help, counsel and rescue those in need. In spiritual persuasions and in all forms of spirituality, it is very important for each and every time to return to biblical sources and to find the strength and meaning in the Holy Scripture both for the victims and their family members. The aim of this chapter is to provide guidelines for spiritual assistance to victims in general and primarily to victims of war crimes of rape.

Spiritual assistance to victims of war crimes of rape as one of the important mechanisms and forms of coping with traumatic experiences, sees its way in thinking about suffering and seeking the path of integrity of a person who is torn inside. The feelings of hatred for the rapist, the anger because the crime happened and could not be avoided, the lesser value because the person was subjected to an inhuman act, often reflect on the wrong images of God. Spiritual illnesses, caused by various traumatic events, prevent a person from being able to control their life freely because the victim lives with the consequences of such event. For this reason, it is necessary to treat the beginnings, that is, the pathogens of the illness so that a person becomes joyful, pure and free from all forms of evil..$^{32}$ But as in other forms of assistance, as well as with spiritual, we can only help a person who wants help. The victim must see and acknowledge the wound itself and forgive those who have wounded her. The goal is to transform all that caused the spiritual illness with the power of faith and the Word of God into spiritual peace and joy. In order for a person to succeed, he or she needs expert help, but also group support that primarily involves family members and friends or whole parish communities. Spiritual help can be provided by every believer who is actively listening to the interlocutor, in this case a victim of war rape. The active listening ${ }^{33}$ of the victim as an interlocutor, but also the interlocutor in general, implies asking questions (showing interest and directing the conversation), facilitating the conversation (through confirmation and appreciation), clarifying unclear claims (requiring further clarification), recognizing unspoken thoughts and feelings that are often hidden

\footnotetext{
${ }^{32}$ Methods of assisting victims may be in the approaches of: Christotherapy as self-help and therapeutic methods (Cf. B. J. TYRRELL, Kristoterapija. Kako ozdraviti pomoću ozdravljenja, Đakovo, UPT, 1996); logotherapy as a treatment with meaning (Cf. Ž. PULJIĆ, Franklova logoterapija - liječenje smislom, Društvena istraživanja - časopis za opća društvena pitanja, 14 (2005) 4-5, 885-902; Szentmartony, Osjetljivost za čovjeka..., 116-117) and hagiotherapy, which through the help and support strives to the healing of the human being; http://www. hagioterapija-split.hr/ (31.01.2019).

${ }^{33}$ Cf. R. NELSON-JONES, Praktične vještine u psihološkom savjetovanju i pomaganju, Jastrebarsko, Naklada Slap, 2007, 135-157; Szentmartony, Osjetljivost za čovjeka..., 83-86.
} 
(e.g. shame, rage, anger, etc.), reflection (which implies helping the interlocutor to hear and understand themselves through repetition of the keywords and articulating their visible emotions), paraphrasing (as a rewording of the pronounced) and summing up (includes clarification, reflection and paraphrasing, conclusions, agreements, and goals).With the skill of active listening we show understanding, we respond to what has been expressed, encourage the person to express more emotions, become aware of their problems and pronounce it; so we strengthen the victim to solve the problem and build a relationship of trust with them. We approach the said problem from the religious side by offering the victim a message of salvation for the forgiveness and the bearing of one's own cross. Since the Church through the Word of God offers a message of salvation, traumatic events in the person are transformed, and brings the victim new meaning and hope in good. But, the support of believers and the Church as a community that prays, believes and strengthens the meaning of life is also very important. ${ }^{34}$ A more quality and more meaningful way of living of rape victims can greatly enable the correct approach, living and glorification of the sacrament of reconciliation that not only forms a conscience through systematic evangelization, but also directs the person to the true sacramental and ecclesial dimension of understanding peace, reconciliation, and suffering experienced. ${ }^{35}$

To pursue the victim's forgiveness, it is necessary to devise pastoral guidelines for dealing with victims of war crimes of rape. Pastoral care is in a special way needed for victims of war crimes of rape as well as members of their families, but also for the entire society that was also wounded by this great evil. Although the Catechism of the Catholic Church points out that faith is a personal act, that is a free human response to the call of God being revealed, it continues that faith is not a lonely act and no one can have faith alone. ${ }^{36}$ That is why spiritual guidance is needed as a pastoral situation in which a believer addresses a priest or other pastoral worker with the issues of his spiritual growth. It is important to know the whole background of the traumatic event as well as the conflicting areas of the attendee because people also use defensive mechanism in their relation to God. Due to the complexity of the situation, the spiritual leader should have the following qualities: self-confidence, ability to overcome conflicts that can arise from his role, recognize cultural, social and political boundaries, embrace strong emotions, feelings and unusual experiences and gain tolerance to pain because of experiences a person they are trying to help went through. In order for a person to heal even spiritual wounds, spiritual help

\footnotetext{
${ }^{34}$ Cf. I. ŽIVKOVIĆ, S. VULETIĆ, Ekleziogene neuroze u psihopatološkim oblicima religioznosti, Društvena istraživanja - časopis za opća društvena pitanja, 92 (2007) 6, 1263-1285, 1281.

${ }^{35}$ Cf. S. ŠOTA, Prispodoba o milosrdnom Ocu i pastoralne smjernice, in: I. RAGUŽ, Š. ŠOKČEVIĆ (ed.), O Božjem milosrdu, Đakovo, Diacovensia, 2016, 115-134.

${ }^{36}$ Cf. HRVATSKA BISKUPSKA KONFERENCIJA, Katekizam Katoličke crkve, Zagreb, Glas Koncila, 1994, no. 166.
} 
should be directed to the biblical and sacramental pastorals. Based on the experience of the victims, we see that it is very important to have continuous and quality monitoring, sacramental life and prayers of members of the Church, especially the parish community. Such a form of assistance should be organized and continuous, and in order to be effective, it is necessary to appoint a Commissioner at the level of the Đakovo-Osijek Archdiocese to work with victims from the Croatian War of Independence who will always be available for individual conversations, organization of spiritual renewals and exercises, public debates, pilgrimages and the like. The priest as a spiritual leader would in this sense be the bridge between the family and the victim, going to the pastoral visits, talking, thinking, preaching and confessing. ${ }^{37}$ Such a commissioner should be present in associations that take care of the victims of the Croatian War of Independence. There is also the need for organized counselling in the pastoral sense, which implies the appointment of professionals and their continuous education, the creation of a pastoral plan and the determination of goals and outcomes. Professional persons should anyway, but even more because of the complexity and difficulty of the subject of war crimes of rape, have a supervisor and have professional help themselves. ${ }^{38}$ The next pastoral guideline is to motivate and strengthen members of parish communities to pray, but also to specifically assist victims of war crimes of rape. Parish communities have played a major and important role during the Croatian War of Independence, which was visible first in prayer support, but also in assisting the most vulnerable, sheltering refugees, caring for meals and preparing winter clothes for soldiers and refugees, and the like. Their support is still needed today by the victims of war rape primarily through prayer, understanding and support. In an organized support network together with the victims who have found courage and faced their traumas, they should go to pastoral visits to parishes of the Đakovo-Osijek Archdiocese, especially in those areas that were the main battlefields during the Croatian War of Independence because the greatest horrors took place in these areas. The purpose of these visits is to support all victims of war rape and to encourage those who have not yet spoken out to do so. A further step is to involve family members of the victims into a continuous spiritual aid program as they are still the most vulnerable centres exempt from psychological, social, and spiritual assistance. In addition to organized spiritual assistance, sometimes it is necessary to organize pilgrimages, spiritual exercises and renewals, meditations, but also excursions and social gatherings in nature with the victims and their families for the purpose of encouraging and connecting victims and their families. Group support and positive atmosphere and the examples of those who overcame difficulties of life give the victims the strength to find a meaning of their suffering. One of the

\footnotetext{
${ }^{37}$ Cf. A. TRSTENJAK, Pastoralna psihologija, Đakovo, UPT, 1989, 143-229.

${ }^{38}$ Cf. Arambašić (ed.), Psihološke krizne intervencije..., 98-103.
} 
guidelines of a better-quality pastoral work is to encourage people who have experienced the crime of rape to form associations, especially within the parish or deanery levels, in order to support, encourage, and build up each other, but also to encourage others to speak out and thus heal or cure their own trauma. ${ }^{39}$

Spiritual assistance to victims of war crimes of rape includes spiritual caring and pastoral counselling such as support, guidance, reflection on one's own suffering through theology of the cross, religious instruction, and the like, and includes the therapeutic knowledge of counsellors / pastoral caregivers enriched with the light of the Christian faith - hagiotherapy. According to the testimonies of the respondents, hagiotherapy is the most comprehensive aspect of the aid provided, not only by the Church but by the entire society. ${ }^{40}$ This type of assistance is very important for the healing of the whole person, but when providing spiritual assistance to the victim of war crime we should be aware of the need for interdisciplinarity as a kind of co-operation of experts from different disciplines that share common goals. A person and a problem are approached from different points of view, thus enabling a more comprehensive attitude towards a complete person. The interaction of various experts is especially needed when it comes to the complex situation and the cruellest form of traumatic experience, such as war crimes of rape. The goal is to restore the meaning of life and reduce human suffering to a minimum and create a fully healed personality.

The question that is often asked is: is it too late today and why didn't the Church approach the victims of war crimes of rape earlier? It is very important to emphasize that it is not too late because the Church, or its caregivers, as well as other experts, have aided the victims from the moment they asked for help. Many priests, psychologists, and psychiatrists are witnessing this reality, who have to keep silent due to the professional secrecy. The aforementioned experts assisted the victims when they asked for help but systematic and continuous work was not possible because they could not, instead of the victims, bring the truth to light until the victims themselves did the first step and spoke out.

Theoretical and empirical research into the war crimes of rape have evidently shown that this problem and its consequences are complex. Since a person is wounded at different levels of human existence, healing is also needed in the same levels. Bearing in mind the need for interdisciplinarity, apart from spiritual aid, victims need to be provided with assistance at all levels of existence that are wounded.

\footnotetext{
${ }^{39}$ Cf. V. GRUDEN, Uloga kluba u liječenju posttraumatskog stresnog poremećaja, in: R. GREGUREK, E. KLAIN (ed.), Posttraumatski stresni poremećaj. Hrvatska iskustva, Zagreb, Medicinska naklada, 2000, 199-201.

${ }^{40}$ Cf. V. GRUDEN, Ožiljci na duši Hrvatske, Zagreb, Medicinska naklada, 1996, 228-230.
} 


\section{Conclusion}

A traumatic event of any kind results in the enduring and serious consequences for the victim's life. The most difficult form of traumatic experience is rape, and the crime of rape in the war reaches extremely high proportions for the lives of victims since the person is being exposed to a larger number of various forms of abuse. Croatian people were not exempt from such horrors during the Greater Serbian aggression in the Croatian War of Independence in the whole country. After defining the war, we looked at the causes of war crimes of rape visible in the attempt of genocide of the Croatian people, superiority to the hostile people, a message proving the differences of power between the warring parties and the defilement and destruction of the female body that represents the destruction of the other nation and country. Rape as a traumatic experience leaves serious consequences visible in the lives of victims and their family members.

After insights into the issue of living with the experience of the trauma of war rape, we have also exposed and through the specific experiences of the victims of war crimes of rape substantiated the facts mentioned about the many consequences that this terrible act leaves on the victim and her family. The victims gathered at the Sunčica Association spoke about the various difficulties which are results of the war crimes of rape. Answering open and closed type questions and even more in the conversation outside the reach of the survey, they spoke of devastating life episodes as well as deep wounds that have not yet healed.

No matter how strong the victims are and how successful in finding strategies to face their own trauma of rape within themselves, they lack the support of the environment, especially the household members and the closest family, and they more often encounter misunderstanding and even disapproval rather than support and assistance. Victims still have problems of inner peace, forgiveness, liberation from hatred, and the like. In order to renew their spirit, they need constant and continuous spiritual assistance in the form of spiritual renewals and exercises, seminars and expert discussions. The Church is especially called upon to sensitize its own members and the society in helping people who have experienced and survived the crime of rape and, in particular, provide systematic assistance to victims and their families.

Since a victim as a person is wounded at all levels, healing is needed on each of them. All of this suggests that, when providing assistance at any level of human existence, care should be taken on the need for an interdisciplinary approach. 
Sanja Kopunović Legetin* - Suzana Vuletić ${ }^{* * * *}-$ Stanislav Šota****

Ratni zločin silovanja u Domovinskom ratu (1991 - 1995)

\section{Sažetak}

Crkva đakovačko-osječka jedna je od biskupija u Republici Hrvatskoj koja je najviše stradala tijekom velikosrpske agresije od 1991. do 1995. godine. Uz pogibije koje su se dogodile tijekom agresije i okupacije velik dio stanovništva, posebice vukovarskog kraja, nakon zarobljavanja izložen je fizičkom, psihičkom i emocionalnom zlostavljanju. Osim protjerivanja, zarobljavanja, prisilnog rada, izgladnjivanja, otuđivanja i prisvajanja imovine u okupiranom dijelu te nadbiskupije dogodila su se i mučenja, posebice mnogobrojna silovanja od strane velikosrpskog agresora. Rad u prvom dijelu govori o naravi rata kao najtragičnijeg događaja civilizacije. Ukazuje na zločine koji su obilježje svakog, pa tako i Domovinskog rata u Republici Hrvatskoj, ističući posebno silovanje kao najbrutalniji oblik zločina i ratne strategije, sa svim mogućim uzrocima i posljedicama koje silovanje ostavlja na čovjeka. U drugom dijelu rada predstavljeni su dijelovi rezultata istraživanja provedenog u udruzi Sunčica. Cilj spomenutog istraživanja bio je doći do konkretnih stavova, prosudbe, stanja i osjećaja žrtava silovanja o samom traumatskom iskustvu, zatim otkriti i procijeniti kvalitetu života žrtava nakon traumatičnog iskustva te identificirati poteškoće s kojima se žrtve susreću i danas. Na temelju istraživanja, rad u trećem dijelu prikazuje načine suočavanja s činjenicom traumatičnog iskustva silovanja, naglašavajući potrebu pružanja socijalne, i još više duhovne pomoći, prikazujući široku lepezu pastoralnih mogućnosti djelovanja Crkve sa žrtvama ratnog zločina silovanja, imajući uvijek u vidu potrebu interdisciplinarnog pristupa kompleksnoj problematici.

Ključne riječi: Domovinski rat, duhovna pomoć, Đakovačko-osječka nadbiskupija, psihološka pomoć, silovanje, udruga Sunčica, velikosrpska agresija.

* Sanja Kopunović Legetin, mag. theol, univ. spec. thel, OŠ »Draž«, Ive Lole Ribara 1, HR-31305 Draž; E-mail: s.kopunovic@gmail.com.

* Izv. prof. dr. sc. Suzana Vuletić, Sveučilište Josipa Jurja Strossmayera Osijek, Katolički bogoslovni fakultet Đakovo, Petra Preradovića 17, HR-31400 Đakovo; E-mail: suzanavuletic007@ gmail.com.

**** Doc. dr. sc. Stanislav Šota, Sveučilište Josipa Jurja Strossmayera Osijek, Katolički bogoslovni fakultet Đakovo, Petra Preradovića 17, HR-31400 Đakovo; E-mail: stanislav.sota@os.t-com.hr. 